\title{
Smorgasbord or symphony? Assessing public health nutrition policies across 30 European countries using a novel framework
}

Ffion Lloyd-Williams ${ }^{1 *}$, Helen Bromley ${ }^{1}$, Lois Orton ${ }^{1}$, Corinna Hawkes ${ }^{2}$, David Taylor-Robinson ${ }^{1}$, Martin O'Flaherty ${ }^{1}$, Rory McGill', Elspeth Anwar ${ }^{1}$, Lirije Hyseni ${ }^{1}$, May Moonan ${ }^{1}$, Mike Rayner ${ }^{3}$ and Simon Capewell ${ }^{1}$

\begin{abstract}
Background: Countries across Europe have introduced a wide variety of policies to improve nutrition. However, the sheer diversity of interventions represents a potentially bewildering smorgasbord.

We aimed to map existing public health nutrition policies, and examine their perceived effectiveness, in order to inform future evidence-based diet strategies.
\end{abstract}

Methods: We created a public health nutrition policy database for 30 European countries. National nutrition policies were classified and assigned using the marketing "4Ps" approach Product (reformulation, elimination, new healthier products); Price (taxes, subsidies); Promotion (advertising, food labelling, health education) and Place (schools, workplaces, etc.). We interviewed 71 senior policy-makers, public health nutrition policy experts and academics from 14 of the 30 countries, eliciting their views on diverse current and possible nutrition strategies.

Results: Product Voluntary reformulation of foods is widespread but has variable and often modest impact. Twelve countries regulate maximum salt content in specific foods.

Denmark, Austria, Iceland and Switzerland have effective trans fats bans.

Price EU School Fruit Scheme subsidies are almost universal, but with variable implementation.

Taxes are uncommon. However, Finland, France, Hungary and Latvia have implemented 'sugar taxes' on sugary foods and sugar-sweetened beverages. Finland, Hungary and Portugal also tax salty products.

Promotion Dialogue, recommendations, nutrition guidelines, labelling, information and education campaigns are widespread. Restrictions on marketing to children are widespread but mostly voluntary.

Place Interventions reducing the availability of unhealthy foods were most commonly found in schools and workplace canteens.

Interviewees generally considered mandatory reformulation more effective than voluntary, and regulation and fiscal interventions much more effective than information strategies, but also politically more challenging.

Conclusions: Public health nutrition policies in Europe appear diverse, dynamic, complex and bewildering. The "4Ps" framework potentially offers a structured and comprehensive categorisation.

Encouragingly, the majority of European countries are engaged in activities intended to increase consumption of healthy food and decrease the intake of "junk" food and sugary drinks. Leading countries include Finland, Norway, Iceland, Denmark, Hungary, Portugal and perhaps the UK. However, all countries fall short of optimal activities. More needs to be done across Europe to implement the most potentially powerful fiscal and regulatory nutrition policies.

Keywords: Public health nutrition, Public health policy, Europe, Food policy mapping, Qualitative

\footnotetext{
* Correspondence: ffionlw@liv.ac.uk

'Department of Public Health \& Policy, Institute of Psychology, Health \&

SocietyUniversity of Liverpool, Whelan Building, Quadrangle, L69 3GB

Liverpool, Merseyside, UK

Full list of author information is available at the end of the article
}

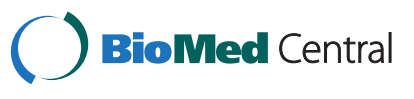

(c) 2014 Lloyd-Williams et al.; licensee BioMed Central Ltd. This is an Open Access article distributed under the terms of the Creative Commons Attribution License (http://creativecommons.org/licenses/by/4.0), which permits unrestricted use, distribution, and reproduction in any medium, provided the original work is properly credited. The Creative Commons Public Domain Dedication waiver (http://creativecommons.org/publicdomain/zero/1.0/) applies to the data made available in this article, unless otherwise stated. 


\section{Background}

Non-communicable diseases account for over $85 \%$ of deaths in Europe [1], and poor diet is responsible for up to $40 \%$ of the non-communicable disease (NCD) burden [2]. Achieving optimal diet strategies could halve the cardiovascular disease burden, and substantially reduce other NCDs $[3,4]$. Food policies are thus under increasing scrutiny in Europe.

Previous studies reviewing European public health nutrition policies are informative yet limited to specific actions and public health nutrition topics. The EuroHeart I study identified cardiovascular prevention strategies in 16 European countries [5] spanning tobacco, public health, physical activity, and food, including some legislative and policy action. The Eatwell project reviewed and evaluated European national healthy eating policies, but focussed mainly on public information campaigns, regulation of meals at schools/canteens and nutrition education programmes. The authors also highlighted the need to measure and compare effectiveness between countries [6].

The PORGROW study examined policy options for responding to the growing challenge from obesity. Respondents from nine EU states indicated that various interventions are required. Interestingly, the costs of various policy options were deemed less important than their social and health benefits, efficacy, acceptability and practical feasibility [7].

The WHO 8 Country study uncovered a wealth of material to support continued development of the implementation of the European NCD Strategy as a flexible policy framework. It thus provided a valuable learning experience for the further policy analyses [8].

The WHO Global nutrition policy review analysed information from 119 WHO Member States including the European region, on the presence of nutrition policies and programmes, topics covered, implementation, the key stakeholders the existence of coordination mechanisms, and monitoring and evaluation processes [9]. The review found most countries had policies and programmes that are addressing key nutrition issues, such as obesity and diet-related NCDs. However, gaps were identified in the design, content and implementation of nutrition policies and programmes [9].

The WHO NOPA database project subsequently aimed to monitor progress on nutrition, obesity and physical activity. At present, the database covers all 53 Member States in the WHO European Region, providing limited information on policy documents, budgets, and any coordinating mechanisms [10]. The Public Health Evaluation and Impact Assessment Consortium noted that much additional data exists in the database, but is not yet publically available [11].

The recent evaluation of the Strategy for Europe on Nutrition, Overweight and Obesity [11] concluded that progress in the development and implementation of nutrition policies has been 'reasonably effective' - within and between countries; however, it has been uneven. Furthermore, most of the action taken thus far at EU and national levels has been 'soft': providing information; limited interventions in schools; and voluntary actions by the food industry. Worryingly, the report cautions that without a new stimulus, political interest at the European level will fade [11].

These studies therefore all highlight that although a variety of policies intended to improve nutrition have been introduced across Europe, their potential effects are not easy to assess. Furthermore, the diverse range of diet interventions represents a potentially bewildering "policy cacophony", a smorgasbord which is difficult to comprehend, categorise or evaluate. As part of the wider EuroHeart II project, we therefore aimed to identify and map public health nutrition policies across Europe, categorise them using a novel "4Ps" framework, and assess their perceived effectiveness. Our findings might then contribute to the debate concerning future evidencebased dietary strategies to prevent cardiovascular disease and other non-communicable diseases.

\section{Methods}

We used a mixed methods comparative study design. A quantitative approach was used to map public health nutrition policy actions in all 30 Western and Central European countries. Semi-structured interviews were then conducted to provide rich detail around the extent of implementation of specific policies, and progress towards national targets.

\section{Study protocol}

A study protocol (Additional file 1) was written as part of the larger EuroHeart II study [12]. The protocol outlined: 1. Specific objectives. 2. Definition of Policies and policy documents (policies relating to CVD and other NCD prevention in relation to food; written documents that contain strategies and priorities, with defined goals and objectives and are issued by a public administration). 3. Approaches for collecting policy documents. 4. Inclusion and exclusion criteria. 5. Analysis and reporting.

\section{Quality control measures}

An advisory group was established comprising the project team together with experts in quantitative and qualitative methodology, and food policy and public health policy analysis. Meeting monthly, quality control was sustained by group discussion upon the design and development of data collection tools, project progress, analysis and reporting of findings. The advisory group ensured that the project timetable was maintained, any issues or problems regarding recruitment and emerging 
findings were discussed and resolved and appropriate dissemination of findings. Furthermore, interview transcripts were analysed by at least two project researchers independently and discrepancies in interpretation of data was discussed until consensus was reached.

\section{Conceptual framework}

To ensure a coherent approach to the mapping of policies in 30 European countries, we developed a conceptual framework. After extensive piloting and reviewing, we agreed the most practical and coherent approach was the "4Ps" marketing mix framework: Product, Price, Promotion and Place (Table 1). An approach used by producers and marketers to systematically assess how well products match their target markets $[13,14]$.

\section{Mapping exercise}

We identified, extracted and categorised public health nutrition policy actions in 30 Western and Central European countries (All EU 27 countries, plus Switzerland, Norway and Iceland) and summarised them in an Excel database. We sought to identify key policy documents in the 30 European countries by searching policy documents, grey literature, nationally important websites (e.g. National Institutes of Public Health, Ministries of Health), and National Nutrition Councils and the WHO European Nutrition, Obesity and Physical Activity (NOPA) database.

The inclusion criteria were government endorsed policy documents covering cardiovascular disease prevention policies or chronic disease in relation to food (e.g. food labelling, legislation on food fat, sugar and salt content etc.) and health focussed taxation or subsidies. Policy documents included: National Acts, Laws, Legislation, Ministerial Decrees (or equivalent); National policies/strategies or plans; and policies/strategies or plans in preparation; social, economic and agricultural policies with a direct effect upon public health nutrition; documents available in English. Information was also collected on the EU school fruit and school milk schemes.

The exclusion criteria were policies relating to micronutrients; policies developed and/or implemented at local/ regional level; polices that had not been implemented.

\section{Table 1 The "4Ps" marketing mix applied to public health nutrition policies

\begin{tabular}{ll}
\hline Price & Taxes; subsidies; or other economic incentives \\
Product & Reformulation; elimination or new products \\
Place & Schools, workplaces or community settings \\
Promotion & $\begin{array}{l}\text { Restricting marketing to children and adults (advertising } \\
\text { controls); nutritional food labelling; nutritional information } \\
\text { on menus; public information campaigns; and health } \\
\text { education }\end{array}$ \\
\hline
\end{tabular}

("Multi-component interventions" might involve a combination of several approaches).
National policy actions were classified according to the "4Ps" conceptual framework.

\section{Interviews with key informants}

To validate the policy database, we conducted interviews with 71 national experts from 14 countries (Belgium, Czech Republic, England, Estonia, Finland, Germany, Greece, Iceland, Italy, Ireland, Malta, Poland, Portugal and Slovenia). The 14 diverse countries were selected as a geographical representation of the 30 European countries, i.e. North, South, East and West. (Limited time and resources prevented us from conducting interviews across all 30 countries). The interviews elicited informant's views on a wide range of potential national public health nutrition polices, initially with a focus on cardiovascular prevention. Interview questions were developed and piloted with key experts in England.

We identified senior food policy makers and topic experts in each country by purposive sampling.

We used various sources including the European Heart Network, national Heart Foundations, the published literature, key websites and 'snowballing' via expert colleagues and networks. We invited potential participants by email, explaining the project and requesting their participation as a national expert in public health nutrition policy. Prior to interview, participants received an information sheet, a consent form, the interview questions and a written summary of public health nutrition policies and related initiatives in their country. The latter two enabled familiarity with the interview content and format. We conducted the subsequent interviews in English, in person, by telephone or Skype. All interviews were digitally recorded and typically lasted from 45 to 60 minutes.

The interviews were transcribed and entered into NVIVO software. A set of broad codes were initially created based upon the interview guide and research objectives. Transcripts were then coded line by line using an inductive method of open coding; whereby researchers allowed patterns and themes to emerge from the data. To ensure the trustworthiness of the coding and interpretations of the data, every fifth transcript was coded in duplicate, and any discrepancies were discussed with a third researcher to reach consensus. Coding of transcripts continued until saturation.

The project team at the Department of Public Health, University of Liverpool, UK, undertook all data analyses. The interview transcripts were analysed using the 'Framework approach' [15] which follows five pre-defined stages: (1) familiarisation, (2) identification of a thematic framework, (3) indexing, (4) charting and (5) mapping and interpretation. Through an in-depth exploration of the emergent findings, the analysis then identified key themes and linkages between them [16]. 


\section{Triangulation, synthesis of mapping exercise and interviews with key informants}

Findings from the interviews were cross checked with the information contained in the policy database. Where applicable, the qualitative information from the interviews was used to illustrate national nutrition policy actions in terms of the "4Ps" framework. The interview data also provided additional information in terms of the perceived effectiveness and cost effectiveness of policy actions and the future actions required to reduce cardiovascular disease.

Further information about the methodology can be found in Additional file 2.

\section{Ethics statement}

The Institute of Psychology, Health and Society Research Ethics Committee at the University of Liverpool, England granted ethical approval for the study. Written consent was obtained from participants taking part in face to face interviews. Verbal consent was obtained from participants interviewed either by telephone or Skype. Verbal consent was transcribed and documented. For all participants consent was obtained before the interview commenced. The ethics committee approved both methods of consent used.

This study adhered to the RATS guidelines for reporting qualitative studies.

\section{Results}

We approached 120 experts for an interview, of which 71 agreed (response rate 59\%). Of the 71 respondents, 59 were experts in food and nutrition, 6 were policy makers and 6 were senior policy makers. Approximately $60 \%$ of the participants were employed in Government Ministries or Universities, about a quarter of the participants represented NGOs and about one tenth of the participants had dual roles, actively participating in or leading NGOs as well as formal government employment.

Tables 2, 3, 4 and 5 provide more detailed information on the findings presented in the results section. The text boxes provide examples of comments made by interview participants (with their country of origin and number assigned to respondent in brackets). The full text of the qualitiative data can be found in Additional file 3 .

Table 2 provides an overview of existing and planned policy actions within all the 30 countries. Subsequent tables summarise activities, based upon the "4Ps" framework in relation to specific nutrients: salt, trans fatty acids and total fat, saturated fats, sugar and fruit and vegetables.

\section{Analysis of food policies across the 30 European countries using the "4Ps" framework} Product: reformulation; elimination or new healthier products Activity relating to "Product" primarily focused upon reformulation, especially salt reduction.

\section{Reformulation: mandatory initiatives}

Thirteen countries have legal requirements regarding the maximum salt content in certain foods (Belgium, Bulgaria, Finland, Greece, Hungary, Latvia, Lithuania, Netherlands, Portugal, Romania, Slovak Republic, Slovenia and Wales) (Table 3).

Trans fat bans exist in Austria, Denmark, Iceland and Switzerland. Denmark was the first country to introduce such legislation in 2003 which strictly regulated the sale of many foods containing trans fats. This was actually preceded by a decade of increasing public and political pressure and stepwise reformulation by industry (Table 4).

Legislation or regulation affecting sugar, fat and fruit and vegetable consumption was uncommon (Only 4 out of the 30 countries). Finland, France and Latvia have legislation affecting sugary products. Latvia has legislation affecting fat and sugary foods, and Slovakia has legislation affecting fruit and vegetables (Table 5).

Many participants commented that the mandatory reformulation of food products was perceived as an effective and cost-effective approach for improving public health nutrition. It was perceived as acceptable to the food industry and the public alike. Food industry profit margins would not be affected and the public would subconsciously be reducing their risk of CVD by eating less salt, sugar and saturated fat in everyday food products (Table 6).

\section{Reformulation: voluntary initiatives}

Voluntary reformulation of foods by the food industry was common, occurring in 25 of the 30 countries, most commonly for salt (Table 3) (e.g. Austria, Belgium, France, Greece, Italy, Malta, Portugal, Romania, Sweden and the UK) (Tables 2, 3, 4 and 5).

Estonia, France and the Netherlands have voluntary reformulation in relation to sugary foods and total fat (Table 5). For example, in France, there is dialogue with industry regarding the fat and sugar content of certain foods and this was included in the Second National Nutrition and Health Programme 2006-2010 (Table 5).

\section{Price: taxes; subsidies and other economic incentives}

Price incentives in different European countries targeted various unhealthy nutrients, including salt, sugar and saturated fat. Taxes to promote healthy nutrition (e.g. fruit and vegetables) are currently only used by six countries. Finland, France, Hungary and Latvia have implemented 'sugar taxes' on sugary foods and sugar-sweetened beverages, while Portugal is the only country that taxes salty products. Hungary taxes food high in fat (Tables 3, 4 and 5).

From 2011, Finland reinstated taxes on sweets (e.g. candies, chocolate, cocoa-based products, ice cream, ice lollies) that existed until 1999. The existing tax on soft drinks was also increased and its scope was widened to cover further categories of beverages. Discussions are being 
Table 2 Mapping of existing and planned policy actions within 30 European countries

\begin{tabular}{|c|c|c|c|c|c|c|c|c|c|c|c|}
\hline \multirow[b]{2}{*}{ Country } & \multicolumn{3}{|c|}{ Price } & \multirow{2}{*}{$\begin{array}{c}\text { Product } \\
\text { Reformulation (V/M) }\end{array}$} & \multicolumn{3}{|c|}{ Place } & \multicolumn{4}{|c|}{ Promotion } \\
\hline & Legislation/Regulation & Taxation & Subsidies $^{\mathrm{a}}$ & & Schools & Workplace & Other settings & Labelling (V/M) & Guidelines $^{\mathbf{b}}$ & $\begin{array}{l}\text { Advertising controls } \\
\text { to children (V/M) }\end{array}$ & Campaigns \\
\hline Austria & $\sqrt{ }$ & $x$ & $x$ & $\mathrm{~V} / \mathrm{M}$ & $\sqrt{ }$ & $\sqrt{ }$ & $x$ & $\mathrm{v}$ & $\sqrt{ }$ & $\mathrm{V} / \mathrm{M}$ & $\sqrt{ }$ \\
\hline Belgium & $\sqrt{ }$ & $x$ & $x$ & $\mathrm{~V} / \mathrm{M}$ & $\sqrt{ }$ & $\sqrt{ }$ & $x$ & v & $\sqrt{ }$ & M & $\sqrt{ }$ \\
\hline Bulgaria & $x$ & $x$ & $\sqrt{ }$ & $\mathrm{V} / \mathrm{M}$ & $M$ & $x$ & $x$ & $x$ & $\sqrt{ }$ & $x$ & $\sqrt{ }$ \\
\hline Cyprus & $x$ & $x$ & $x$ & v & $\sqrt{ }$ & $x$ & $x$ & $\sqrt{ }$ & $\sqrt{ }$ & v & $\sqrt{ }$ \\
\hline Czech Republic & $x$ & $x$ & $x$ & $\mathbf{v}$ & $x$ & $x$ & $x$ & v & $\sqrt{ }$ & v & $\sqrt{ }$ \\
\hline Denmark & $\sqrt{ }$ & $\sqrt{ }$ & $x$ & $\mathrm{~V} / \mathrm{M}$ & v & v & v & v & $\sqrt{ }$ & M & $\sqrt{ }$ \\
\hline Estonia & $\sqrt{ }$ & $x$ & $x$ & v & $M$ & v & $x$ & v & $\sqrt{ }$ & v & $\sqrt{ }$ \\
\hline Finland & $\sqrt{ }$ & $\sqrt{ }$ & $x$ & $\mathrm{~V} / \mathrm{M}$ & $M$ & M & $x$ & M & $\sqrt{ }$ & v & $\sqrt{ }$ \\
\hline France & $\sqrt{ }$ & $x$ & $x$ & v & $\sqrt{ }$ & $\sqrt{ }$ & $x$ & M & $\sqrt{ }$ & v & $\sqrt{ }$ \\
\hline Germany & $x$ & $x$ & $x$ & v & $\sqrt{ }$ & $\sqrt{ }$ & $\sqrt{ }$ & v & $\sqrt{ }$ & v & $\sqrt{ }$ \\
\hline Greece & $\sqrt{ }$ & $x$ & $x$ & v & $M$ & $x$ & $\sqrt{ }$ & $x$ & $\sqrt{ }$ & v & $\sqrt{ }$ \\
\hline Hungary & $\sqrt{ }$ & $\sqrt{ }$ & $x$ & $\mathrm{~V} / \mathrm{M}$ & $\sqrt{ }$ & $\sqrt{ }$ & $x$ & v & $\sqrt{ }$ & $\mathrm{V} / \mathrm{M}$ & $\sqrt{ }$ \\
\hline Iceland & $\sqrt{ }$ & $x$ & $x$ & v & $x$ & $x$ & $x$ & $M$ & $\sqrt{ }$ & $M$ & $\sqrt{ }$ \\
\hline Ireland & $x$ & $x$ & $x$ & v & $x$ & $\sqrt{ }$ & $\sqrt{ }$ & v & $\sqrt{ }$ & $M$ & $\sqrt{ }$ \\
\hline Italy & $x$ & $x$ & $x$ & v & $x$ & $\sqrt{ }$ & $x$ & $x$ & $\sqrt{ }$ & v & $\sqrt{ }$ \\
\hline Latvia & $x$ & $\sqrt{ }$ & $x$ & $M$ & $M$ & $x$ & $M$ & $x$ & $\sqrt{ }$ & $M$ & $\sqrt{ }$ \\
\hline Lithuania & $x$ & $x$ & $x$ & $M$ & $M$ & $\sqrt{ }$ & $x$ & $\mathrm{~V} / \mathrm{M}$ & $\sqrt{ }$ & $M$ & $\sqrt{ }$ \\
\hline Luxembourg & $x$ & $x$ & $x$ & 0 & $\sqrt{ }$ & $\sqrt{ }$ & $x$ & 0 & $\sqrt{ }$ & & $\sqrt{ }$ \\
\hline Malta & $x$ & $x$ & $x$ & v & $M$ & $\sqrt{ }$ & $x$ & 0 & $\sqrt{ }$ & 0 & $\sqrt{ }$ \\
\hline Netherlands & $x$ & $x$ & $x$ & $\mathrm{~V} / \mathrm{M}$ & $x$ & $\sqrt{ }$ & $x$ & $M$ & $\sqrt{ }$ & $M$ & $\sqrt{ }$ \\
\hline Norway & $\sqrt{ }$ & $x$ & $\sqrt{ }$ & $x$ & $x$ & $x$ & $x$ & v & $\sqrt{ }$ & $M$ & \\
\hline Poland & $x$ & $x$ & $x$ & v & $\sqrt{ }$ & $x$ & $x$ & v & $\sqrt{ }$ & $x$ & $\sqrt{ }$ \\
\hline Portugal & $\sqrt{ }$ & $\sqrt{ }$ & $x$ & V/M & $\sqrt{ }$ & $x$ & $\sqrt{ }$ & v & $\sqrt{ }$ & v & $\sqrt{ }$ \\
\hline Romania & $\sqrt{ }$ & $x$ & $x$ & $\mathrm{~V} / \mathrm{M}$ & $M$ & $x$ & $x$ & v & $\sqrt{ }$ & v & $\sqrt{ }$ \\
\hline
\end{tabular}


Table 2 Mapping of existing and planned policy actions within 30 European countries (Continued)

\begin{tabular}{|c|c|c|c|c|c|c|c|c|c|c|c|}
\hline Slovakia & & $\overline{\sqrt{ }}$ & $x$ & V/M & $\overline{\sqrt{ }}$ & $x$ & $\bar{x}$ & $\mathrm{~V}$ & $\sqrt{ }$ & $\mathrm{v}$ & $\overline{\sqrt{ }}$ \\
\hline Slovenia & $\sqrt{ }$ & $x$ & 0 & V/M & M & $\sqrt{ }$ & $x$ & V & $\sqrt{ }$ & V/M & $\sqrt{ }$ \\
\hline Spain & $x$ & $x$ & $x$ & v & $\sqrt{ }$ & $\sqrt{ }$ & $x$ & $M$ & $\sqrt{ }$ & v & $\sqrt{ }$ \\
\hline Sweden & $x$ & $x$ & $\sqrt{ }$ & v & M & $\sqrt{ }$ & $x$ & V & $\sqrt{ }$ & $M$ & $\sqrt{ }$ \\
\hline Switzerland & $\sqrt{ }$ & $x$ & $x$ & $M$ & $x$ & $x$ & $x$ & 0 & $\sqrt{ }$ & & \\
\hline UK & $\sqrt{ }$ & $x$ & $x$ & v & $\sqrt{ }$ & $\sqrt{ }$ & $x$ & $M$ & $\sqrt{ }$ & $M$ & $\sqrt{ }$ \\
\hline
\end{tabular}

Data current to end of February 2013

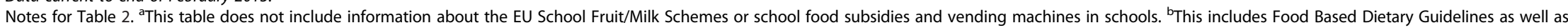
other guidelines e.g. Guidelines for healthy nutrition in primary schools or hospitals.

$\sqrt{ }=$ Yes

$\mathbf{X}=$ No.
$\mathbf{O}=$ Unclea

$\mathbf{O}=$ Unclear.
$\mathbf{V}=$ Voluntary

$\mathbf{V}=$ Voluntary.
$\mathbf{M}=$ Mandatory

$\mathbf{V} / \mathbf{M}=$ Both (e.g. Mandatory for salt, voluntary for saturated fat). 
Table 3 Existing and planned policy actions in relation to salt within $\mathbf{3 0}$ European countries Country Action: Salt

\begin{tabular}{ccc}
\hline $\begin{array}{c}\text { Price (Legislation/regulation/ } \\
\text { subsidies) }\end{array}$ & Product (Reformulation) & $\begin{array}{c}\text { Place (Schools, workplace, } \\
\text { other settings) }\end{array}$
\end{tabular}

\section{Promotion (Labelling/ guidelines/advertising controls/campaigns}

Austria
Salt Reduction Program "Less
Salt is Healthier" ("Weniger Salz
ist g'sünder") Joint initiative
between Ministry of Health
and the Industrial Bakers of
Austria. Aims at reducing the
salt content in bakery products
by $15 \%$ by 2015 . Dialogue with
food industry bread, meat,
ready meals.

\begin{tabular}{|c|c|}
\hline Belgium & $\begin{array}{l}\text { Legislation since } 1985.2 \% \\
\text { maximum salt content in bread. }\end{array}$ \\
\hline
\end{tabular}

2009: Ordinance established to reduce salt content of foods in school canteens. For 2011-2012, an updated ordinance includes healthy nutrition and salt reduction in kindergarten school canteens.
Guidelines for school catering. Salt reduction in National Since the beginning of $2012 \quad$ Nutrition Plan 2011. Dietary salt the implementation of these guidelines take place as part of the initiative "Our School Catering" ("Unser Schulbuffet"). target.
Salt Strategy: Stop Salt (selfregulation adopted by food industry, distribution sector, restaurant and catering school sector). Special ordinance for healthy nutrition at schools 2009 and 2011. Food products with a high content of salt are not allowed.
Salt Strategy: Stop Salt Self-regulation adopted by food industry, distribution sector, restaurant and catering school sector.

Salt strategy/policy included in the National Food and Nutrition Action Plan 2005-

2010. The 2007 National Salt Initiative set a target for consumption of $5 \mathrm{~g} /$ day.

\begin{tabular}{lc}
\hline Cyprus & \\
\hline Czech & $\begin{array}{c}\text { Gradual reduction of sodium } \\
\text { levels in dried soups and } \\
\text { seuces to } 50 \% \text { of the Guideline } \\
\text { Daily Amounts i.e. } 1.2 \text { grams of } \\
\text { sodium or less. }\end{array}$ \\
\hline
\end{tabular}

Denmark

New strategy to reduce

Dialogue with industry regarding reduction of salt content in bread.

\begin{tabular}{cc}
\hline Estonia & Salt policy included in National \\
& Health Plan 2009-2020 and in \\
& the National Strategy for CVD \\
& $2005-2020$.
\end{tabular}
population salt intake adopted 2011-12.

Finland National legislation on compulsory 'warning labelling' of high salt foods since 1980s. Tightened 2009. Upper limit to salt content of eligible products e.g. cheese 1.3\%. 2011: Quality criteria to obtain subsidies for meals at university restaurants renewed, contain limits for salt in main meals and all meal components.

\section{Health Plan 2009-2020 and in 2005-2020.}

Industry led discussion.

\begin{tabular}{|c|c|c|c|}
\hline France & $\begin{array}{l}\text { Bakery industry reducing salt in } \\
\text { bread. Dietary salt target. }\end{array}$ & & \\
\hline Germany & & $\begin{array}{l}\text { Recommendations to reduce } \\
\text { salt intake are included in all } \\
\text { national quality standards for } \\
\text { meals in schools, } \\
\text { kindergartens, homes for the } \\
\text { elderly, canteens at the work } \\
\text { place, food on wheels-services. }\end{array}$ & $\begin{array}{c}\text { Nutrition considered a } \\
\text { comprehensive approach } \\
\text { within the line of the national } \\
\text { "In Form" Action Plan. A } \\
\text { dialogue with industry will be } \\
\text { taken up where considered } \\
\text { necessary. }\end{array}$ \\
\hline
\end{tabular}




\section{Table 3 Existing and planned policy actions in relation to salt within $\mathbf{3 0}$ European countries (Continued)}

Greece
Legal requirement re: max level
of salt permitted in bread, tomato
juice and tomato concentrates/
purees since 1971. Max level -
nutrient profiles that serve as
the scientific basis for legislation
regarding the list of foods
allowed to be sold in school
canteens include maximum
sodium level requirements.
Level of sodium in biscuits:
$0.5 \mathrm{~g} / 100 \mathrm{~g}$ since 2006 .
Codex Alimentarius Hungaricus
modified salt content for bread
and some other bakery products
(on dry matter).
Tax: Act Clll on public health
product tax: salty snacks with
salt content exceeding $1 \mathrm{~g} / 100 \mathrm{~g}$
and condiments (soup and other
powders, artificial seasonings)
above $5 \mathrm{~g}$ salt $/ 100 \mathrm{~g}$ (2011). Max
level 'Nutritional recommendation
for mass caterers' draft proposal
for a ministerial decree -
Recommendation issued (ministerial
decree is in progress).

Iceland

Ireland

Setting benchmarks for salt reduction, reformulation.
Hellenic Food Authority working with food manufacturers to reformulate processed products high in salt.
Nutrient profiles that serve as the scientific basis for legislation regarding the list of foods allowed to be sold in school canteens include requirements. maximum sodium level
Salt strategy mentioned in the Action Plan for Implementation of the National Nutrition Policy.
Dietary salt target. Salt included in in Hungarian National Nutrition Action Plan 2010-2013.

\begin{tabular}{c}
\hline Italy \\
July 2009 - Voluntary Agreement \\
between associations of craft \\
bakers and plant bakers and \\
Ministry of health to reduce salt \\
content in some of their \\
products. Ref: P. Strazzullo, \\
G. Cairella, A. Campanozzi, M. \\
Carcea, et al. for the GIRCSI \\
Working Group 1.
\end{tabular}

Latvia $\begin{aligned} & \text { Dietary standards in schools, } \\ & \text { kindergartens, long-term social } \\ & \text { care institutions and hospitals }\end{aligned}$
(2012).
Course of action for Nursery school, Primary and Secondary school children and Foster Home Nutrition, article 17 prohibits confectionary which contains sodium >0,4 g/100 g (2011).

\begin{tabular}{cc}
\hline Lithuania & Course of action for Nursery \\
school, Primary and Secondary \\
school children and Foster Home \\
Nutrition, article 17 prohibits \\
confectionary which contains \\
sodium $>0,4 \mathrm{~g} / 100 \mathrm{~g}(2011)$.
\end{tabular}

Luxembourg
Malta
Dialogue with industry to reduce salt began in 2010 .

National salt reduction initiative focuses on bread only
Multilevel awareness raising public campaigns; cooperation with the food industry; and monitoring and evaluation.

Salt strategy included in Changing Cardiovascular Health, National Cardiovascular Health Policy 2010-2019.

Dietary salt target.

National salt reduction initiative since 2008 in line with EU target of $16 \%$ Reduction by 2013. Population based strategy for dietary salt intake reduction: Italian initiatives in the European framework Nutrition, Metabolism and Cardiovascular Diseases, 22(3) 2012 161-166.

Salt maximum level - Dietary standards in schools, kindergartens, long-term social care institutions and hospitals.

Salt maximum level - Dietary standards in schools, kindergartens, long-term social care institutions and hospitals.
As of 2008 initiatives discussed with bakers and butchers federations.

Dietary Salt Target

Salt mentioned in a Strategy for the Prevention and Control of NCDs in Malta 2010. 
Table 3 Existing and planned policy actions in relation to salt within $\mathbf{3 0}$ European countries (Continued)

\begin{tabular}{cc}
\hline Netherlands & Bread max. 2.5\% salt on dry \\
& matter, tightened to max. $2.1 \%$ \\
salt on dry matter (1.8\% salt in & flour). 2013 it will be tightened \\
again to $1.8 \%$ salt on dry matter \\
(1.5\% in flour).
\end{tabular}

Norway

( $1.5 \%$ in flour).

Banned all food advertising targeting children aged

younger than 12 years since

1990. National salt initiative

reduction is linked to the

Action Plan on Nutrition

(2007-2011), “Recipe for a healthier diet".

Salt reduction included in the National Prevention

Programme of Overwieght,

Obesity and Non-communcable

Disease through Diet and Physical

Activity Improvement 2007-2011 and the national Health

Programme 2007-2015.Dietary

Salt TargetSalt initiatives being developed as of 2010. Ministry of

Health financed salt reduction programme 2009-2011.

\begin{tabular}{ccc}
\hline Portugal & $\begin{array}{c}\text { Tax introduced } 2012 \text { for VAT on } \\
\text { salty products. }\end{array}$ & $\begin{array}{c}\text { Law adopted August } 2009 \text { to } \\
\text { set the maximum content of } \\
\text { salt in bread. }\end{array}$ \\
Voluntary Initiatives with the food \\
industry.
\end{tabular}$\quad \begin{gathered}\text { Voluntary Initiatives with the } \\
\text { food industry. }\end{gathered}$

Law adopted August 2009 to set the maximum content of salt in bread and enact guidelines for the labelling of pre-packaged foods for human consumption, compelling the inclusion of visible data on the relative and absolute quantity of salt on the packaging.

\begin{tabular}{|c|c|c|c|c|}
\hline Romania & $\begin{array}{l}\text { Ministerial Order 1563/2008: Food } \\
\text { with salt content above } 1.5 \mathrm{~g} \\
\text { salt/100 g or } 0.6 \mathrm{~g} \text { sodium } / 100 \mathrm{~g} \\
\text { not allowed to be sold in schools. }\end{array}$ & $\begin{array}{l}\text { The Ministry of Health and } \\
\text { Romalimenta are in the } \\
\text { process of signing an } \\
\text { agreement for the } \\
\text { reformulation of foods with } \\
\text { salt. Voluntary reformulation } \\
\text { meat and bread products by } \\
\text { industry. }\end{array}$ & $\begin{array}{l}\text { Ministerial Order } 1563 / 2008 \text { : } \\
\text { Food with salt content above } \\
1.5 \mathrm{~g} \text { salt } / 100 \mathrm{~g} \text { or } 0.6 \mathrm{~g} \\
\text { sodium/100 } \mathrm{g} \text { not allowed to } \\
\text { be sold in schools. }\end{array}$ & \\
\hline Slovakia & $\begin{array}{l}\text { National legislation, focus on } \\
\text { maximum level of salt in some } \\
\text { food categories since } 1996 . \\
\text { Currently preparing an } \\
\text { amendment. }\end{array}$ & $\begin{array}{l}\text { Voluntary by some food } \\
\text { business operators. }\end{array}$ & & $\begin{array}{c}\text { Salt strategy mentioned in the } \\
\text { National Obesity Prevention } \\
\text { Programme. }\end{array}$ \\
\hline Slovenia & $\begin{array}{l}\text { Nutritional recommendation for } \\
\text { salt content in bread and meat } \\
\text { products since } 2010 \text {. }\end{array}$ & & & $\begin{array}{l}\text { Discussion with food industry } \\
\text { (Chamber of Commerce) } \\
\text { started in } 2009 \text { with a seminar } \\
\text { in April 2010. The National } \\
\text { Action Plan for Salt was } \\
\text { adopted in July 2010. And a } \\
\text { national salt campaign was } \\
\text { launched in May } 2010 \text { to March } \\
\text { 2011. Salt strategy included in } \\
\text { National Programme of Food } \\
\text { and Nutrition Policy 2005-2010. } \\
\text { Salt specific programme. }\end{array}$ \\
\hline Spain & & $\begin{array}{l}\text { Voluntary by industry. } \\
\text { Agreement with Bakery } \\
\text { Confederation regarding salt } \\
\text { reduction in bread. }\end{array}$ & & $\begin{array}{l}\text { Salt strategy mentioned in the } \\
\text { Strategy for Nutrition, Physical } \\
\text { Activity and Prevention of } \\
\text { Obesity (NAOS) (Schafer Elinder } \\
\text { and Bollars). }\end{array}$ \\
\hline
\end{tabular}




\section{Table 3 Existing and planned policy actions in relation to salt within $\mathbf{3 0}$ European countries (Continued)}

\begin{tabular}{|c|c|c|c|c|}
\hline Sweden & & & & $\begin{array}{l}\text { Banned all food advertising } \\
\text { targeting children aged younger } \\
\text { than } 12 \text { years since } 1990 . \\
\text { Government has dialogue with } \\
\text { food industry as of } 2010 \text {. Salt } \\
\text { strategy/policy mentioned in } \\
\text { "Healthy Habits and Increased } \\
\text { Physical Activity", the basis for } \\
\text { an Action Plan. }\end{array}$ \\
\hline Switzerland & & $\begin{array}{l}\text { Negotiating with industry to } \\
\text { reduce salt in bread and } \\
\text { processed foods.The big food } \\
\text { manufacturers and retailers } \\
\text { made commitments in line } \\
\text { with the EU Framework. }\end{array}$ & & $\begin{array}{l}\text { Salt strategy } 2008-2012 \\
\text { included public awareness } \\
\text { campaigns and a commitment } \\
\text { to work with the food industry. }\end{array}$ \\
\hline \multirow[t]{3}{*}{ UK } & $\begin{array}{c}\text { Wales: max level - mandatory } \\
\text { requirements for foods vended in } \\
\text { hospitals requiring hospital caterers } \\
\text { to vend lower salt products (as } \\
\text { defined by FSA traffic light labelling } \\
\text { criteria). }\end{array}$ & $\begin{array}{c}\text { England, Northern Ireland, } \\
\text { Scotland, Wales: Voluntary by } \\
\text { industry. }\end{array}$ & $\begin{array}{l}\text { Wales: max level - mandatory } \\
\text { requirements for foods vended } \\
\text { in hospitals requiring hospital } \\
\text { caterers to vend lower salt } \\
\text { products (as defined by FSA } \\
\text { traffic light labelling criteria). }\end{array}$ & $\begin{array}{l}\text { A voluntary consistent system } \\
\text { of front-of-pack food labelling } \\
\text { has been introduced: A } \\
\text { combination of colour coding } \\
\text { and nutritional information is } \\
\text { used to show how much fat, } \\
\text { salt and sugar and how many } \\
\text { calories are in each product. }\end{array}$ \\
\hline & & & $\begin{array}{c}\text { As part of the government's } \\
\text { Responsibility Deal, } 49 \\
\text { companies/retailers have } \\
\text { agreed to provide calorie } \\
\text { information on menus and } \\
\text { display boards. Although } \\
\text { voluntary, the label must } \\
\text { follow a standard government } \\
\text { model. }\end{array}$ & $\begin{array}{c}\text { Since November 2006, Ofcom, } \\
\text { an independent } \\
\text { communications regulator in } \\
\text { the UK, announced a ban on } \\
\text { television advertising of } \\
\text { products high in fat, salt or } \\
\text { sugar during children's airtime } \\
\text { and around programmes with } \\
\text { a disproportionately high child } \\
\text { audience. }\end{array}$ \\
\hline & & & & $\begin{array}{l}\text { England, Northern Ireland, } \\
\text { Scotland, Wales:; National Salt } \\
\text { reduction strategy. }\end{array}$ \\
\hline
\end{tabular}

Data current to end of February 2013.

held to further extend this tax (Table 5). In 2012, the French Government introduced a tax on sugar-sweetened drinks including artificially sweetened drinks (fruit juices with added sugars, water, carbonated drinks containing added sugar) (Table 5). In 2011, Hungary introduced a public health product tax on snacks with a salt content exceeding $1 \mathrm{~g} / 100 \mathrm{~g}$ and condiments (soup and other powders, artificial seasonings) above $5 \mathrm{~g}$ salt /100 g; plus taxes on soft drinks, prepacked sweetened products and energy drinks (Table 3).

In October 2011, Denmark was the first country to introduce a tax on saturated fats (meat, cheese, butter, margarine, snacks, etc.) with the intention of decreasing consumption levels by $4 \%$ [17]. However, following coordinated action by the food industry, the tax was repealed in November 2012 (Table 5).

The majority of interview respondents felt that "Price" incentives such as taxes, legislation and regulation were the most effective options for improving public health nutrition (Table 7).

Subsidises for healthy food products were uncommon, apart from the almost universal EU School Fruit Subsidy
Scheme. Co-funded by the EU and individual Member States, this voluntary scheme aimed to encourage good eating habits in young people by making fruit and vegetables available to children in schools. In addition, participating Member States were required to set up strategies including educational and awareness-raising initiatives. However, target groups, take-up and implementation of the scheme has varied widely, making comparisons between countries difficult.

"... if there is taxation or subsidies, there should be legislation and regulation, you can't divide them. For example for school fruit scheme we need legislation as well. But I think that subsidies might be one possibility just to offer cheaper healthy foods. Or to subsidise to influence farmers to grow fruit." (Estonia 3)

Promotion health education, public information \& campaigns, advertising controls, food labelling Information and health education Information campaigns targeted at the general population were widespread 
Table 4 Existing and planned policy actions in relation to trans fatty acids

\begin{tabular}{|c|c|c|c|c|}
\hline \multirow[t]{2}{*}{ Country } & \multicolumn{4}{|c|}{ Action: Trans Fatty Acids (TFAs) } \\
\hline & $\begin{array}{l}\text { Price (Legislation/ } \\
\text { regulation/subsidies) }\end{array}$ & Product (Reformulation) & $\begin{array}{l}\text { Place (Schools, } \\
\text { workplace, } \\
\text { other settings) }\end{array}$ & $\begin{array}{l}\text { Promotion (Labelling/guidelines/ } \\
\text { advertising controls/campaigns }\end{array}$ \\
\hline Austria & TFAs banned since 2003 & & & \\
\hline Belgium & & $\begin{array}{l}\text { Voluntary reformulation on sugary } \\
\text { foods, fat and TFAs. }\end{array}$ & & $\begin{array}{l}\text { Working group formed } 13.01 .12 \text { to } \\
\text { examine Saturated Fat, TFAs, sugar, } \\
\text { portion size and fibre in bread flour. }\end{array}$ \\
\hline Denmark & TFAs banned since 2003 & & & \\
\hline Estonia & & & & $\begin{array}{l}\text { TFAs policy included in the National } \\
\text { Strategy for the prevention of CVD } \\
2005-2020 \text {. }\end{array}$ \\
\hline Germany & & & & $\begin{array}{l}\text { 2012: Joint initiative of the German } \\
\text { Food Sector and the Ministry of } \\
\text { Nutrition, Agriculture and Consumer } \\
\text { Protection (BMELV) concerning } \\
\text { "Guidelines to minimize TFAs in food": } \\
\text { Giving practical recommendations to } \\
\text { industry how to further reduce non- } \\
\text { ruminant (industrial) TFA in food. }\end{array}$ \\
\hline \multirow[t]{2}{*}{ Hungary } & $\begin{array}{l}\text { Draft ministerial decree on the } \\
\text { maximum levels of TFAs in } \\
\text { foodstuffs. }\end{array}$ & & & \\
\hline & $\begin{array}{l}\text { A ministerial decree has been } \\
\text { drafted to set up a limit for the } \\
\text { trans fatty acid content of } \\
\text { foodstuffs being on the market, } \\
\text { taking into account the WHO } \\
\text { recommendation for daily trans } \\
\text { fatty acid intake. The professional } \\
\text { consultation of the content of the } \\
\text { draft decree is ongoing. }\end{array}$ & & & \\
\hline Iceland & $\begin{array}{l}\text { TFAs legislation since August } \\
\text { 2011. TFAs (less than } 2 \% \text { per } \\
100 \mathrm{~g} \text { fat). }\end{array}$ & & & \\
\hline Italy & & $\begin{array}{l}\text { Discussions to improve partnership } \\
\text { with food industry. Some important } \\
\text { results have been reached, like the } \\
\text { reduction of trans-fats from sweet } \\
\text { products. Some voluntary agreements } \\
\text { have been reached with sweet } \\
\text { producers regarding elimination of } \\
\text { trans-fats. }\end{array}$ & & \\
\hline Netherlands & & $\begin{array}{l}\text { Voluntary by industry - total fat, TFAs } \\
\text { and sugary foods. }\end{array}$ & & \\
\hline Spain & & Voluntary by industry & & $\begin{array}{c}\text { Voluntary by industry TFAs strategy } \\
\text { mentioned in the Strategy for Nutrition, } \\
\text { Physical Activity and Prevention of } \\
\text { Obesity (NAOS) (Schafer Elinder and } \\
\text { Bollars). }\end{array}$ \\
\hline Switzerland & TFAs banned since 2008 & & & \\
\hline UK & & Voluntary by industry & & \\
\hline
\end{tabular}

Data current to end of February 2013.

(Table 2). The majority focussed upon general healthy eating messages and or campaigns targeted at reducing childhood obesity. Some countries also highlighted specific nutritional topics such as salt (e.g. Belgium, England, Estonia, Ireland, Italy, and Slovenia). However, participants generally perceived such interventions to have limited impact (Table 8).

Many countries include nutrition education as a mandatory part of the school curriculum (Austria, Bulgaria, Denmark, Estonia, Finland, France, Germany, Ireland, Latvia, Lithuania, 
Table 5 Existing and planned policy actions in relation to total fat, saturated fats, sugar and fruit and vegetables Country Action: Total Fat, Saturated Fats (SFs) and sugar

\begin{tabular}{cc}
\hline $\begin{array}{c}\text { Price (Legislation/regulation/ Product (Reformulation) } \\
\text { subsidies) }\end{array}$ & $\begin{array}{c}\text { Place (Schools, workplace, } \\
\text { other settings) }\end{array}$
\end{tabular}

Promotion (Labelling/ guidelines/advertising controls/campaigns

Austria

Guidelines for school catering.

Since the beginning of 2012

the implementation of these

guidelines take place as part of

the initiative "Our School

Catering" ("Unser Schulbuffet").

\begin{tabular}{lc}
\hline Belgium & $\begin{array}{c}\text { Voluntary reformulation on } \\
\text { sugar, SFs and TFAs. }\end{array}$
\end{tabular}

The provision of free or subsidized fruit and vegetables, as well as a ban on unhealthy food in vending machines at school are only partially enforced, and dealt with at local level.
Dialogue and some action with July 2009 ordinance of the meat products, bread/bakery Ministry of Health adopted. products and soft drinks Mandatory provision of school

producers. Actions are all cafeteria with vegetables, fruits
regional or local level.
and other healthy foods, and regional or local level.
Working group on SFs, TFAs, sugar, portion size and fibre in bread flour set up 13.01.12.

\begin{tabular}{c}
\hline Bulgaria \\
Special ordinance for healthy \\
nutrition at schools 2009 and \\
2011, introduced 2011-12. \\
Bulgarian State standard covers \\
milk products, Bulgarian yellow \\
cheese, standards for meat and \\
poultry products including \\
sausage.
\end{tabular}
the restriction of sales of energy-dense and nutrient-poor foods and beverages in school canteens, cafeteria and vending machines. Food products with a high content of fat and sugar are not allowed.

\section{Cyprus}

Some efforts have been made to remove unhealthy food and beverages from school vending machines.

\begin{tabular}{|c|c|}
\hline \multirow[t]{2}{*}{ Denmark } & $\begin{array}{l}\text { SF tax on foods with over } 2.3 \% \\
\text { Sat Fat introduced Oct } 2011 ; \\
\text { repealed Nov } 2012 .\end{array}$ \\
\hline & $\begin{array}{l}2009 \text { introduction of the } \\
\text { "Spring Package" included an } \\
\text { increase of fiscal taxes on } \\
\text { confectionary and soft drinks } \\
\text { and investigated the } \\
\text { possibilities of creating a fiscal } \\
\text { tax on SF. Has had levy on } \\
\text { candy for } 90 \text { years. }\end{array}$ \\
\hline
\end{tabular}

Estonia

The National Health Development Plan for Estonia contains specific actions regarding removal of energydense nutrient poor foods and beverages in school vending machines.

\begin{tabular}{|c|c|c|c|c|}
\hline Finland & $\begin{array}{c}\text { Agricultural subsidies to } \\
\text { encourage dairy farmers move } \\
\text { to berry production. } \\
\text { Tax currently exists for soft } \\
\text { drinks, ice cream and chocolate. } \\
\text { Discussions under way to } \\
\text { increase this tax. Aim of the } \\
\text { standing government is to have } \\
\text { an agreement on general tax } \\
\text { on sugary foods before the year } \\
\text { 2013. All food in Finland taxed } \\
\text { at } 13 \% \text { despite calls for fruit } \\
\text { and vegetables to be taxed less } \\
\text { or not at all. }\end{array}$ & $\begin{array}{c}\text { Voluntary action industry led } \\
\text { regarding SFs. }\end{array}$ & $\begin{array}{l}\text { Quality of school meals } \\
\text { regulated by Ministry of } \\
\text { Education and Culture. } 2007 \\
\text { recommendations that vending } \\
\text { machines should not provide } \\
\text { sweets and beverages in } \\
\text { schools. }\end{array}$ & $\begin{array}{l}\text { Voluntary action Guidelines on } \\
\text { how to include nutritional } \\
\text { criteria (such as SFs) in food } \\
\text { service procurements were } \\
\text { implemented late } 2009 \text {. }\end{array}$ \\
\hline
\end{tabular}

Restaurants must be able to

prove that the courses on the menu marked with the "Keyhole" symbol lives up to the expectations of being low salt and high in the content of fibre. 
Table 5 Existing and planned policy actions in relation to total fat, saturated fats, sugar and fruit and vegetables (Continued)

\begin{tabular}{cc}
\hline France & A tax on sugar sweetened \\
beverages became effective in \\
January 2012. The tax was set \\
at about 11 euro cents for a 1.5 \\
litre of soda, about $6 \%$ of the \\
average price of sodas.
\end{tabular}

Greece average price of sodas.
Dialogue with industry regarding reducing fat and sugar in food products.
Vending machines not allowed in school settings since 2005 .

Local level initiatives ensuring a choice of healthy food at the workplace.
Dialogue with industry regarding Included in Second National Nutrition and Health

Programme 2006-2010.

\begin{tabular}{|c|c|c|}
\hline & & not allowed in schools. \\
\hline & & $\begin{array}{l}\text { Draft ministerial decree on the } \\
\text { nutritional-health provisions in } \\
\text { public catering. }\end{array}$ \\
\hline Hungary & $\begin{array}{l}\text { A "public health tax" adopted in } \\
2012 \text { is applied on the salt, sugar } \\
\text { and caffeine content of various } \\
\text { categories of ready-to-eat foods, }\end{array}$ & $\begin{array}{l}\text { Recommendations for healthy } \\
\text { schools buffet options included } \\
\text { in government resolution on } \\
\text { education. }\end{array}$ \\
\hline & $\begin{array}{l}\text { including soft drinks (both sugar- } \\
\text { and artificially-sweetened), energy } \\
\text { drinks, pre-packaged sugar- } \\
\text { sweetened products. }\end{array}$ & $\begin{array}{l}\text { Local level initiatives to ensure } \\
\text { a choice of healthy food at the } \\
\text { workplace. }\end{array}$ \\
\hline
\end{tabular}

Iceland

Regulation 1924/2006

establishes EU-wide rules on the use of specified nutrient content and comparative claims (i.e. levels of fat for a low fat claim). Nutrition claims can only be used on foods defined as "healthy" by a nutrient profile (nutrient profile not yet defined).

\begin{tabular}{|c|c|c|c|}
\hline Ireland & & $\begin{array}{l}\text { Recommendations regarding } \\
\text { the choice of healthy food at } \\
\text { the workplace within the Happy } \\
\text { Heart at Work Programme ". } \\
\text { Happy Heart at Work Healthy } \\
\text { Eating Award (Ended 2012) } \\
\text { designed by Irish Heart } \\
\text { Foundation to assist employers } \\
\text { provide healthy food choices in } \\
\text { the workplace. Also a 'Happy } \\
\text { Heart Catering Award' in the } \\
\text { northeast of the country which } \\
\text { targets cafes, hotels, pubs etc. }\end{array}$ & $\begin{array}{l}\text { Discussions to develop } \\
\text { initiatives to reduce the content } \\
\text { of fat and/or sugars in } \\
\text { processed foods. }\end{array}$ \\
\hline Italy & $\begin{array}{l}\text { Discussions to improve } \\
\text { partnership with food industry } \\
\text { and develop initiatives to } \\
\text { increase the availability of } \\
\text { processed foods with reduced } \\
\text { fat/added sugars. Ministry of } \\
\text { Health has been encouraging } \\
\text { the primary producers and the } \\
\text { processing industry to } \\
\text { progressively reduce the total } \\
\text { content of fat, saturated fats, } \\
\text { sugar and added salt in food } \\
\text { products. Some voluntary } \\
\text { agreements have been reached } \\
\text { with the bakery industry } \\
\text { (regarding salt reduction), } \\
\text { sweet producers (regarding } \\
\text { elimination of trans-fats) and } \\
\text { retailers (through a national } \\
\text { information campaign that } \\
\text { encourages fruits and vegetables } \\
\text { consumption }\end{array}$ & $\begin{array}{l}\text { The National Plan of Prevention } \\
\text { and the regional "Gaining health" } \\
\text { schemes endorse several } \\
\text { projects to promote healthy } \\
\text { nutrition in the workplace. }\end{array}$ & \\
\hline
\end{tabular}


Table 5 Existing and planned policy actions in relation to total fat, saturated fats, sugar and fruit and vegetables (Continued)

2012: Dietary standards in
Latvia
social care institutions and
hospitals. Sausages, frankfurters,
dried, smoked, salted meat and
fish products, factory made ravioli,
frozen manufactured meatballs
and fish fingers, etc. are allowed
once a week if they contain at
least 70\% meat or 60\% fish;
Increased taxes on food high
in fat, salt (other than sodium),
and sugar nutrients.

2006: Government implemented legislation that prohibited the sale/availability of soft drinks, drinks with added colours, sweeteners, preservatives and caffeine on all school premises. 2012: Dietary standards in schools, kindergartens, long-term social care institutions and hospitals.

\begin{tabular}{l}
\hline Lithuania \\
\hline Luxembourg \\
\hline Malta \\
\\
\hline Netherlands \\
\end{tabular}

\section{5 restrictions on unhealthy}

food in school catering, especially vending machines.

National and local level efforts to remove energy-dense nutrientpoor foods and beverages in school vending machines.

Vending machines not allowed in any public schools and most private schools.

Dutch Nutrition Centre has implemented some actions promoting healthy nutrition at work.

\begin{tabular}{lc}
\hline Norway & Regulation 1924/2006 \\
establishes EU-wide rules on & Banned all food advertising \\
the use of specified nutrient & younger than 12 years since \\
content and comparative claims & 1990. \\
(i.e. levels of fat for a low fat \\
claim). Nutrition claims can only \\
be used on foods defined as \\
"healthy" by a nutrient profile \\
(nutrient profile not yet \\
defined).
\end{tabular}

As of 2010 initiatives being discussed but reformulation of

fat and sugary foods not a priority at present.
Government discussing total fat and sugar content of processed food products.

Portugal

Encourage the provision of healthy food products in schools.

Guidelines exist for restaurants as part of Platform Against Obesity. By Nov 2010 86,000 enterprises had implemented the guidelines.

\section{Developments to increase availability of processed foods with reduced content of total fat and/or sugar through the National Platform Against Obesity.}

\begin{tabular}{cc}
\hline Slovakia & 2009 VAT reduced from 16\% to \\
$9 \%$ for farm products - especially \\
milk, fruit and vegetables. Direct \\
support for fruit and vegetables \\
especially organic and integrated \\
production, which allows for \\
lower prices of fruits and \\
vegetables for consumers.
\end{tabular}

Slovenia
Food guidelines and legislation

2010. Vending machines

banned all primary and

secondary schools. 
Table 5 Existing and planned policy actions in relation to total fat, saturated fats, sugar and fruit and vegetables (Continued)

\section{Spain}

National legislation proposed 2010 regarding vending machines in schools needs to be adopted by regional governments. July 2010 recommendations and technical criteria for the feeding and food supplies in schools. Free/

subsidized F\&V schemes being developed.

\section{Sweden}

All unprocessed food stuffs are zero-rated value-added tax. A range of unhealthy foods have standard rated value-added tax.

As of 2010 Education Act requires in all schools (kindergarten, primary, secondary) that school meals have to be nutritious. Guidelines from the National Food Administration on planning, producing and serving healthy food at school have also been issued.
All food in state schools
(voluntary in academies) must
meet nutritional standards.
Meals must include high-quality
meat, poultry or oily fish, at least
2 portions of fruit and vegetables
with every meal, bread, other
cereals and potatoes. No fizzy
drinks, crisps, chocolate or
sweets in school meals and
vending machines and no
more than 2 portions of deep-
fried food a week.

Various workplace initiatives taken to ensure a choice of healthy food.

\footnotetext{
As part of the government's Responsibility Deal, 49 companies/retailers have agreed to provide calorie information on menus and display boards. Although voluntary, the label must follow a standard government model.
}

\begin{abstract}
A voluntary consistent system of front-of-pack food labelling has been introduced: A combination of colour coding and nutritional information is used to show how much fat, salt and sugar and how many calories are in each product.
\end{abstract}

Since November 2006, Ofcom, an independent communications regulator in the UK, announced a ban on television advertising of products high in fat, salt or sugar during children's airtime and around programmes with a disproportionately high child audience002E.

The Change4Life Convenience Stores programme is a partnership between the UK Department of Health and the Association of Convenience Stores to increase the availability of fresh fruit and vegetables in convenience stores in deprived, urban areas in England with poor existing retail access to fresh fruits and vegetables.

Data current to end of February 2013.

Portugal, Slovakia, Slovenia, Sweden, and UK) and most are also actively improving the nutritional value of foods available in schools.

\section{Labelling}

Food labelling of nutritional composition was common (Table 2). 21 countries had some form of labelling; however, presentation and information varied widely. Since 2009 it has been mandatory in Portugal to list the salt content of food and the sodium content in bread is restricted to a maximum of $14 \mathrm{~g} / \mathrm{kg}$ (Table 3). Under current EU regulations, nutrition labelling is optional, but becomes compulsory if a nutrition/health claim is made on the label. Some countries have adopted nutritional logos. For example, 
Sweden, Norway, Denmark and Iceland adopted the 'Keyhole' scheme as a joint nutrition label. This is a voluntary scheme for food producers, but products labelled with the symbol must conform to nutritional regulations in different food groups (i.e. fat, saturated fat, salt, sugar and fibre). Similar schemes exist in other countries, for example, in Finland ("healthy heart" logo) and the Netherlands ("choices" logo).

Participants perceived labelling as being effective; but felt however, that nutritional information labelling needs to be easy to identify (i.e. front of pack) and straightforward to read and interpret (Table 9).

\section{Dialogue recommendations and guidelines}

Dialogue, recommendations and guidelines are often an early part of the policy process and are widespread (Table 2).

Marketing of foods high in fat, salt and sugar to children Although many of the 30 countries were self-regulating, 12 countries had mandatory regulations against marketing to children (Austria, Belgium, Denmark, Hungary, Iceland, Ireland, Latvia, Lithuania, Netherlands, Slovenia, Sweden, and UK). Only a few had regulations for advertising in schools, while many had general regulations for advertising to children but which were not food-specific. Sweden had banned any advertising targeted at children under 12 but because of EU legislation, the ban only covered broadcasts originating in Sweden. In 2011, Iceland introduced a new media law banning adverts adjacent to programmes aimed at children under 12 years as well as provisions regarding commercial communications and teleshopping (Table 2).

Interviewees perceived mandatory measures around marketing of foods high in fat, salt and sugar as clearly being more effective than self regulation (Table 10).

\section{Place schools and workplaces}

Place interventions aim to modify food quality or availability in specific settings. The majority were situated in schools and, to a lesser extent, workplaces (Table 2). Interventions primarily focused on the removal of vending machines, or replacing the contents of vending machines (now offering healthy snacks), and legislation, regulation or recommendations on food offered in canteens. Many countries are actively improving the nutritional value of foods available in schools.

Participants felt that interventions targeted in school settings or preschool (kindergarten) settings were effective (Table 11).

\section{Exemplary food policies and future aspirations}

All 71 interviewees were also asked about exemplary food policies and future policy options. These topic experts and policy makers across the 14 countries consistently perceived legislative and regulatory approaches as being generally more effective at improving public health nutrition than voluntary approaches, or information or education campaigns.

Table 7 Price: comments on taxes and other economic incentives

Comment
"...legislation and regulation. Because with voluntary actions you will get little wins in the short term but not all actors will be moving
and with regulation you get one rule for everyone so there is less inequity..."
"I think it is necessary to adopt more laws ... maybe taxes on, higher taxes on junk food and therefore the healthier food would be
cheaper."
"I think the taxation is very effective. I would go to taxation of the sugar because it is how it is used now and how people drink the soft
drinks and eat candies so I would tax it more..."
"...maybe taxation could be most cost effective, however there is a problem of political costs of such activity. Taxing probably products
rich in saturated fats. Then products like sweeties which are high in calories and also which are rich in saturated fat and sugar."


Table 8 Information and health education

Comment
"...they (the Government) always like information and communication campaigns because they prefer to have visibility. That's also sometimes Belgium 2
a problem because in the first place they want some concrete visible action instead of structural changes but in fact it is always a
combination of those options in fact."
"Certainly the Government would be most willing to do, would be giving some money for education and information campaigns, which in my Germany 1
opinion would be the least effective."
"I think we can forget education and information campaigns. OK they are good but they are not going to be very effective. So I think the most Iceland 1
effective points would be legislation, regulation and taxation."

\section{Table 9 Labelling}

Comment
"... We need the information but we have many people who don't read the labels and that's why we need the labelling on the front of packages
and the symbols are important..."
"So sometimes you have to have both; not only legislation but also try to have information and education and also try to work with
parents and teachers and so on. It's also important to help with labelling because they do not often know how to read the labelling..."
"I think if you're going to provide people with that sort of information it should be understandable and usable and appropriate."

Table 10 Marketing to children

\begin{tabular}{|c|c|c|}
\hline \multicolumn{2}{|l|}{ Comment } & Source \\
\hline \multicolumn{2}{|l|}{$\begin{array}{l}\text { "Stronger control over marketing of unhealthy foods to children, I would certainly put that high as a priority. It's controllable, it's achievable, l'd } \\
\text { actually possibly put that up there as perhaps the most achievable. It clearly can be done through control over advertising." }\end{array}$} & England 3 \\
\hline \multicolumn{2}{|l|}{$\begin{array}{l}\text { "Like in advertising, a consensus paper has been written with the food industry about advertising... it has been until now difficult to legislate } \\
\text { so we have worked in terms of consensus. But we will try in the future, when it will be possible to have some legislation..." }\end{array}$} & Portugal 2 \\
\hline Comment & \multicolumn{2}{|c|}{ Source } \\
\hline $\begin{array}{l}\text { "... I think nutritional recommendations for school canteens and it is necessary to adopt in law I think. Not only recommendations but } \\
\text { law for nutritional content of lunches. And to ban some content of vending machines in schools." }\end{array}$ & \multicolumn{2}{|c|}{ Czech Republic 3} \\
\hline $\begin{array}{l}\text { "But we will try in the future, when it will be possible to have some legislation. We have done that in the schools, in the schools it is not } \\
\text { possible to have the fat in food; it is not possible to sell it. And sugar is not possible to sell... that is a regulation for schools." }\end{array}$ & \multicolumn{2}{|c|}{ Portugal 2} \\
\hline
\end{tabular}

\section{Perceived cost-effectiveness of regulation versus voluntary measures}

Participants across all 14 European countries also perceived regulatory measures to be more cost-effective than voluntary measures. The most popular modifiable dietary risk factors to focus upon were salt, trans fat and saturated fat (England, Finland, Germany, Greece, Iceland, Ireland, Portugal, Slovenia). Taxation was highlighted by participants in Czech Republic, Germany, Iceland, Ireland, Poland and Slovenia.

Future requirements to improve public health nutrition Participants in thirteen of the 14 European countries perceived legislation and regulation as necessary for improving public health nutrition. Legislation specifically relating to reformulation was identified as necessary by experts in Belgium, England, Estonia, Finland, Germany, Greece, Italy, Portugal and Slovenia. Taxation was also deemed important by participants in Belgium, Czech Republic, England, Finland, Greece, Iceland, Ireland, Poland, Portugal and Slovenia.

\section{Discussion}

\section{Main findings}

The 30 Western and Central European countries studied are at very different stages of addressing healthy diet strategies. For example, countries such as Finland, Hungary and Portugal all have legislation and taxation to improve public health nutrition, whereas Cyprus, Germany and Lithuania do not have such strategies in place. Dialogue, recommendations and guidelines are widespread, but represent an early and uncontroversial part of the policy process. Likewise information and education campaigns which are widespread and include campaigns for the general population, and more targeted campaigns in schools, the workplace and within communities. Many include 
general healthy eating messages, while some countries also highlighted specific nutritional topics such as salt or fruit and vegetables. However, many expert respondents considered such "downstream" interventions to have limited effectiveness, correctly reflecting published evaluations $[11,18,19]$.

Conversely, taxation or regulation is still uncommon. Though many of our respondents correctly perceived these "upstream" interventions as being much more effective and powerful, these are also seen as politically more challenging $[11,18,19]$.

New EU legislation has introduced mandatory "back of pack" nutrition labelling and countries need to adopt this by 2016 [20]. However, 'front-of-pack' nutrition labelling remains voluntary [21]. Some countries require more detailed information about the nutritional value of foods. However, presentation and the information provided vary widely. Some key informants correctly emphasised that although consumers may look at nutrition labelling, they may remain confused by the information presented.

Mandatory reformulation of products to reduce salt and saturated fat remain uncommon, even though they are generally agreed to be more effective by our policy makers, and by researchers [19,22]. Barely a dozen European countries have regulations regarding the maximum salt content in certain foods.

Food taxes are currently used effectively in a few, notable countries for sugar (Finland, France, Hungary, Latvia) or salt (Portugal) The brief Danish Fat Tax experiment in 2011/12 was unsuccessful but has perhaps provided useful lessons for countries considering the future implementation of "fat taxes" [23].

Advertising food and beverages can powerfully affect children's food choices and food intake [24]. Some governments have therefore agreed voluntary schemes with large food and beverage manufacturers to try and limit the marketing of these products to children. However, the recent EU media directive merely encourages governments to encourage media service providers to develop codes of conduct. Furthermore, our topic experts were sceptical about the effectiveness of voluntary codes, echoing previous critiques $[24,25]$.

\section{Comparisons with other studies}

This work provides a 2012 "snap-shot" and analysis of diverse policy actions relating to public health nutrition across Europe. It complements and builds on previous studies. In particular, it extends the WHO 8 countries study, and the PORGROW study (9 countries) and EuroHeart I study (16 countries), [5,7,8]. It also provides further detail of recent promising interventions, notably the percieved effectiveness of all policies including taxation and regulation. It thus contrasts with the Eatwell project (partnered with industry), which paradoxically emphasised voluntary approaches. Our findings are also reassuringly consistent with those in the WHO NOPA website (NOPA) [10].

Voluntary approaches were generally viewed sceptically. The European Platform for Action on Diet, Physical Activity and Health [26] is a European Commission led forum for European-level organisations, the food industry and consumer protection NGOs. The Platform aimed to provide examples of coordinated action by different parts of society that will encourage national, regional or local initiatives across Europe. However, a recent evaluation has queried its effectiveness [18].

The recent PHEIAC external evaluation of the Strategy for Europe on Nutrition, Overweight and Obesity [11] was comprehensive and robust, noting that progress within and between countries has been "uneven". Furthermore, most of the actions taken thus far have been "soft", relying mainly on providing information, limited schools interventions or voluntary actions by the food industry [11]. Our findings endorse these criticisms.

It is gratifying to see that our key observations have been replicated by others. Most notably the multicountry review and survey of policymakers 2014 [27] and NOURISHING [28], the World Cancer Research Fund International's policy framework to promote healthy eating. The former surveyed policymakers, from legislative and executive branches of government, in 11 countries - Brazil, Bulgaria, Canada, Denmark, England, France, Germany, Italy, Mexico, Spain and the United States. They found policymakers' perceptions of national policy and knowledge of policies and the impact of different approaches differed, both in terms of whether they are a good course of action and whether they are currently in place and effective. NOURISHING have found that many countries have taken food policy actions to address obesity and NCDs. Many more policies have been implemented which remain unreported or unknown. However, overall progress is disproportionately low compared to the size of the burden of noncommunicable diseases and the challenges of unhealthy food environments and diets.

\section{Strengths and limitations}

Our project has many strengths. It represents the most up to date and comprehensive mapping exercise detailing food policies across 30 countries in Western and Central Europe. The "4Ps" framework of Product, Price, Promotion and Place offers a potentially useful tool to help create order out of the "policy cacophony" [3].

In 14 diverse countries, detailed policy analysis, visits and interviews with a diverse range of local experts and stakeholders permitted verification and triangulation. The qualitative interviews enabled a more in-depth examination of 
the findings from the mapping exercise, and allowed verification of current and future policy actions within countries. The interviews also provided rich detail around perceptions of the most effective policies, the extent of their implementation, and the progress towards specific national targets.

This project also has clear limitations. Firstly, our data may not be complete, particularly in the 16 countries where in-depth interviews were not undertaken. However, most of these countries were previously examined in the EuroHeart 1 or WHO studies, thus major omissions in terms of policies are unlikely. Secondly, there was a disproportionate number of experts in food and nutrition interviewed. A number of additional policy makers were approached but declined, many stating that they were too busy to take part, or that they were unwilling to express their personal views. Thirdly, our study provides only a snapshot of activities up until 2012. We recognise that developments are on-going and will certainly require regular monitoring and updating (ideally in collaboration with colleagues from $\mathrm{WHO}$ and other organisations). Fourthly, because we guaranteed anonymity to our respondents, this might limit the details of organisation and hence context. Fourthly, the category "promotion" is uncomfortably broad ranging from media campaigns down to to individual health education. This merits further work. Finally, during the developmental phase, we considered various candidate frameworks, such as the "3As" model used in tobacco control (Affordability, Acceptability, and Accessibility), and Chow et al. "Environmental influences" approach (Policy/ Legislation; Public Information; Societal norms; and Neighbourhood environments) [29]. The "4Ps" framework is not flawless. It has no formal hierarchy and possibly provides an arbitrary categorisation of a continuum of policy actions. However, it appears to perform well in practice, and has withstood criticism since first publication in 2011 [14]. This simple framework offers a logical way to categorise different actions and potentially assists to create some order out of the complexity of policy actions.

\section{Implications for future public health nutrition policies}

Encouragingly, the majority of European countries are actively engaged in activities to improve their public health nutrition and decrease the intake of junk food and sugary drinks. Countries demonstrating notable progress include Finland, France, Hungary, Iceland, Portugal and perhaps the UK. Furthermore, looking now beyond Europe, exemplary policies have been successfully implemented to substantially reduce salt, trans fats and refined sugars and increase the consumption of fruit, vegetables and other wholefood in select countries around the world. Thus, exemplar policies for salt reduction might highlight not only Finland, Hungary, Iceland, Portugal and the UK, but also Argentina, Turkey, Japan and Fiji [30]. Likewise, exemplary countries for industrial transfats elimination or reduction might include not only Denmark, Switzerland, Austria, and Iceland, but also the USA and Korea [31].

\section{Conclusions}

Implications for future research

Public health nutrition policies in Europe represent a complex, dynamic and rapidly changing arena. The diverse public health nutrition activities across 30 European countries might initially appear complex and bewildering. However, the "4Ps" framework offers a potentially structured and comprehensive categorisation of these diverse interventions. We therefore now propose future work to further develop the "4Ps" framework, then identify and evaluate population-based policy actions carried out across the entire WHO European Region (53 countries).

However, there is clearly no room for complacency. The coverage and implementation of existing nutrition policies remains patchy and variable, a "smorgasbord" rather than a symphony. It is quite logical that countries develop approaches to promote healthy diet that fit the local and cultural situation. This will ultimately involve setting priorities and making choices with a wide range of stakeholders. Yet, increasing evidence suggests that legislation, regulation and taxation will have the greatest impact upon populations in terms of reducing many NCDs and obesity.

Mandatory approaches are clearly more effective than voluntary schemes. Yet most European countries fall well short in their use of the most effective and powerful "upstream" interventions: legislation, regulation, taxation and subsidies. Based upon this premise we recommend the following actions to be considered at the European and national level:

- Mandatory reformulation of products to reduce salt, saturated fat and trans fats.

- Increased availability and quality of healthy foods available in school canteens and vending machines.

- Further salt reduction targets and elimination of industrial trans fats.

- Restriction of marketing/advertising of junk foods and sugary drinks to children.

- Duties on sugary drinks and subsidies for fruit, vegetables and other healthy options.

\section{Additional files}

Additional file 1: Study Protocol.

Additional file 2: Methodology.

Additional file 3: Qualitative Interview Findings.

Competing interests

The authors declare that they have no competing interests. 


\section{Authors' contributions}

SC led the project. SC, FLW, LO, HB, DTR, MOF, MM, CH and MR helped to design and deliver the project. FLW, HB, LO, LH and MM undertook and analysed the interviews. FLW, HB and SC wrote the paper with input and approval from all authors.

\section{Acknowledgements}

We wish to thank all EuroHeart Steering Group Members for their ongoing support in the development, delivery and dissemination of this study. Funding for the study was provided by the European Union Health Programme (Executive Agency for Health \& Consumers). "EuroHeart II". (European Heart Health Strategy 2). (ADONIS code A/100946). The funders had no role in study design, data collection and analysis, decision to publish, or preparation of the manuscript.

\section{Author details}

${ }^{1}$ Department of Public Health \& Policy, Institute of Psychology, Health \& SocietyUniversity of Liverpool, Whelan Building, Quadrangle, L69 3GB Liverpool, Merseyside, UK. 'World Cancer Research Fund International, London, UK. ${ }^{3}$ University of Oxford, Oxford, UK.

Received: 15 May 2014 Accepted: 10 October 2014

Published: 21 November 2014

\section{References}

1. European NCD Alliance: NCD Alliance Report 2012-2013 Putting noncommunicable diseases on the global agenda. http://ncdalliance.org/sites/default/ files/rfiles/NCD\%20Alliance\%20Report\%202012-2013.pdf (accessed 01.08.2013).

2. Murray CJL, Vos T, Lozano R, Naghavi M, Flaxman AD, Michaud C, Ezzati M, Shibuya K, Salomon JA, Abdalla S, Aboyans V, Abraham J, Ackerman I, Aggarwal R, Ahn SY, Ali MK, AlMazroa MA, Alvarado M, Anderson HR, Anderson LM, Andrews KG, Atkinson C, Baddour LM, Bahalim AN, BarkerCollo S, Barrero LH, Bartels DH, Basáñez M-G, Baxter A, Bell ML, et al: Disability-adjusted life years (DALYs) for 291 diseases and injuries in 21 regions, 1990-2010: a systematic analysis for the Global Burden of Disease Study 2010. Lancet 2013, 380(9859):2197-2223.

3. Mozaffarian D, Capewell S: United Nations' dietary policies to prevent cardiovascular disease. BMJ 2011, 343:d5747.

4. World Health Organisation Media Centre: Obesity and Overweight Factsheet No.311. WHO; http://www.who.int/mediacentre/factsheets/fs311/en/ (accessed 01.08.13).

5. Cowburn G, Bhatnagar P, Løgstrup S: Cardiovascular disease prevention in Europe - the unfinished agenda. In EuroHeart work package 5: National plans, policies and measures impacting on cardiovascular health promotion and cardiovascular disease prevention. Brussels, Belgium: European Union Public Health Programme; 2009.

6. Pérez-Cueto FJA, Aschemann-Witzel J, Shankar B, Brambila-Macias J, Bech-Larsen T, Mazzocchi M, Capacci S, Saba A, Turrini A, Niedzwiedzka B, Piorecka B, Kozioł-Kozakowska A, Wills J, Traill WB, Verbeke W: Assessment of evaluations made to healthy eating policies in Europe: a review within the EATWELL Project. Public Health Nutr 2012, 15(08):1489-1496.

7. Lobstein T, Millstone E: Policy options for responding to obesity Summary report of the EC-funded project to map the view of stakeholders involved in tackling obesity - the PorGrow project. SPRU; 2006. http://www.sussex.ac.uk/ spru/research/kplib/archives/porgrow.

8. Ritsatakis A, Makara P: Gaining health: Analysis of policy development in European countries for tackling noncommunicable diseases. Copenhagen, Denmark: World Health Organisation; 2006.

9. WHO: Global nutrition policy review: What does it take to scale up nutrition action? WHO; (http://apps.who.int/iris/bitstream/10665/84408/1/ 9789241505529_eng.pdf). accessed 12.04.14.

10. WHO: European database on nutrition, obesity and physical activity (NOPA). http://data.euro.who.int/nopa/ (accessed 01.08.13).

11. Public Health Evaluation and Impact Assessment Consortium" (PHEIAC): Evaluation of the implementation of the Strategy for Europe on Nutrition, Overweight and Obesity related health issues. Final Report SANCO/2008/01/ 055; 2013 http://ec.europa.eu/health/nutrition_physical_activity/docs/ pheiac_nutrition_strategy_evaluation_en.pdf accessed 01.08.2013.

12. European Heart Network: EuroHeart II Project: Building Action on Heart Disease and Stroke. http://www.ehnheart.org/euroheart-ii.html accessed 12.04.14.
13. McCarthy EJ: Basic Marketing: A Managerial Approach. Illinois, US: Homewood; 1960.

14. European Heart Network: Diet, Physical Activity and Cardiovascular Disease Prevention in Europe. Brussels: EHN; 2011.

15. Ritchie J, Spencer $L, O^{\prime}$ Connor W: Carrying out qualitative data analysis in Ritchie J and Lewis J. In Qualitative Research Practice: A guide for socia scientists and researchers. London: Sage; 2003:219-286.

16. Pope C, Ziebland S, Mays N: Analysing qualitative data. BMJ 2000, 320:114-116.

17. EPHA database: Update October 2012 Food taxation in Europe: Evolution of the legislation. http://www.epha.org/a/4814 (accessed 01.08.13).

18. The Evaluation Partnership: Evaluation of the European Platform for Action on Diet, Physical Activity and Health. Final report, Specific Contract No 2. Brussel s: DG Sanco; 2010.

19. Stuckler D, Nestle M: Big food, food systems, and global health. PLOS Med 2012, 9(6):e1001242. doi:10.1371/journal.pmed.1001242.

20. European Food Information Council (EUFIC): Global Update on Nutrition Labelling. Brussels, Belgium: EUFIC; 2013.

21. European Union Regulation: (EU) No 1169/2011 of the European Parliament and of the Council of 25 October 2011. http://eur-lex.europa.eu/LexUriServ/ LexUriServ.do?uri=OJ:L:2011:304:0018:0063:EN:PDF (accessed 01.08.2013).

22. Sharma LL, Teret SP, Brownell KD: The food industry and self-regulation: Standards to promote success and to avoid public health failures. Am J Public Health 2010, 100:240-246. doi:10.2105/AJPH.2009.160960.

23. Jensen JD, Smed S: The Danish tax on saturated fat - short run effects on consumption, substitution patterns and consumer prices of fats. Food Policy 2013, 42:18-31.

24. Galbraith-Emami S, Lobstein T: The impact of initiatives to limit the advertising of food and beverage products to children: a systematic review. Obes Rev 2013, doi:10.1111/obr.12060.

25. World Health Organisation Regional Office for Europe Marketing of foods high in fat, salt and sugar to children: update $2012-2013$. http://www.euro.who.int/_data/assets/pdf_file/0019/191125/e96859.pdf (accessed 01.08.13).

26. EU Platform for Action on Diet, Physical Activity and Health. Annual Report 2011 http://ec.europa.eu/health/nutrition_physical_activity/docs/ eu_platform_2011frep_en.pdf.

27. European Association for the Study of Obesity and C3 Collaboration for Health. In Obesity Perception and Policy: Multi-Country Review andSsurvey of Policy Makers 2014. http://easo.org/wp-content/uploads/2014/05/ C3_EASO_Survey_A4_Web-FINAL.pdf (accessed 14.08.14).

28. World Cancer Research Fund International: Food Policy Highlighightlights from around the World 2014. http://www.wcrf.org/sites/default/files/ PPAFoodPolicyHighlights.pdf (accessed 14.08.14)

29. Chow CK, Lock K, Teo K, Subramanian SV, McKee M, Yusuf S: Environmental and societal influences acting on cardiovascular risk factors and disease at a population level: a review. Int J Epidemiol 2009, 38:1580-1594. doi:10.1093/ije/dyn258

30. Webster JL, Dunford EK, Hawkes C, Neal BC: Salt reduction initiatives around the world. J Hypertension 2011, 29:1-5.

31. Downs SM, Thow AM, Leeder SR: The effectiveness of policies for reducing dietary trans fat: a systematic review of the evidence. Bull World Health Organ 2013, 91(4):262-269. doi:10.2471/BLT.12.111468.

\section{doi:10.1186/1471-2458-14-1195}

Cite this article as: Lloyd-Williams et al:: Smorgasbord or symphony? Assessing public health nutrition policies across 30 European countries using a novel framework. BMC Public Health 2014 14:1195. 